Acta Theriologica 37 (1 - 2): 141 - 162, 1992.

PL ISSN $0001-7051$

\title{
Skull variability of Mustela nivalis Linnaeus, 1766 in Poland
}

\author{
Krzysztof SCHMIDT
}

\begin{abstract}
Schmidt K. 1992. Skull variability of Mustela nivalis Linnaeus, 1766 in Poland. Acta theriol. 37: $141-162$.

The skull variability of Mustela nivalis Linnaeus, 1766 was studied with regard to age, sexual dimorphism and geographical distribution. The material consisted of 271 skulls from Poland. Linear dimensions of weasel skulls slightly increased with age. The changes in skull proportions were related to braincase diminution and increase in viscerocranium. In females, there was an obvious age variation in correlation structures which indicated synchronic growth and periods of stabilization. Sexual dimorphism was expressed by larger dimensions and different proportions in male skulls. The values of coefficients of variation were higher in males than females. Adult skull size was reached earlier by females than by male weasels. The correlation structures of male and female skulls were different. The skull dimensions increase from north-east to south-west Poland. It was revealed, that weasels from Poland but Silesia belong to the subspecies Mustela nivalis vulgaris Erxleben, 1777. Weasels from Silesia may probably form a separate subspecies Mustela nivalis trettaui Kleinschmidt, 1937.

Mammal Research Institute, Polish Academy of Sciences, 17-230 Białowieża, Poland

Key words: Mustela nivalis, skull variability, sexual dimorphism, age variation, geographical variation
\end{abstract}

\section{Introduction}

The weasel (Mustela nivalis Linnaeus, 1766) is a wide-spread species in almost the whole of the Holarctic and it was also introduced to New Zealand (Lever 1985). This species was the subject of many studies over its whole range. Problems relating to it's taxonomy, ecology and morphology were studied by: Barbu (1968) in Romania, Erlinge $(1975,1979)$ in Sweden, King $(1975,1980)$ in Great Britain, Frank (1985) in Germany, as well as Ralls and Harvey (1985) in North America. The age, sex and geographical variation of weasel skulls in Europe have also been studied (Kratochví 1951, 1977; Reichstein 1957, 1986; Fog 1969, Mazák 1970, Douma-Petridou and Ondrias 1987). It can then be said that the species is morphologically well known. However many doubts still exist concerning intraspecies variation of the weasel in Europe. For example, ranges of certain subspecies (Mustela nivalis boccamela Bechstein, 1801, Mustela nivalis vulgaris Erxleben, 1777 and Mustela nivalis nivalis Linnaeus, 1766) are still not well 
defined. Moreover, many authors do not agree with distinguishing the subspecies M. n. trettaui Kleinschmidt, 1937.

There is no detailed morphological characeristic of this species from Poland. Although papers by Kleinschmidt (1937) and Zimmermann (1940) concerned areas belonging to Poland now (Silesia), they had only a faunistic character. The aim of this study is an analysis of the age, sex and geographical variation of weasel skulls from Poland, and to establish its subspecies status and range.

\section{Material and methods}

\section{Material}

Skulls of 271 weasels (154 males and 117 females) from Poland were studied (Fig. 1, Table 1). Materials from the following collections were used: Mammal Research Institute, Polish Academy of Sciences in Białowieża $(n=220)$, Natural History Museum of Wrocław Univerity in Wrocław $(n=43)$, Upper Silesia Museum in Bytom ( $=3$ ), Institute of Systematics and Evolution, Polish Academy of Sciences in Cracow $(n=4)$ and Warsaw Agricultural University in Warsaw $(n=1)$. The weasels were most frequently caught accidentally during studies on other small mammals between 1907 to 1988 .

\section{Age criteria and classes}

The following age criteria were analysed:

(1) Degree of ossification of sutures: sutura internasalis, s. nasomaxillaris, s. frontomaxillaris, s. nasofrontalis and s. maxillo-intermaxillaris. These criterion was used by King (1980) in the case of the weasel and by Buchalczyk and Ruprecht (1977) in the case of the common polecat (Mustela putorius).

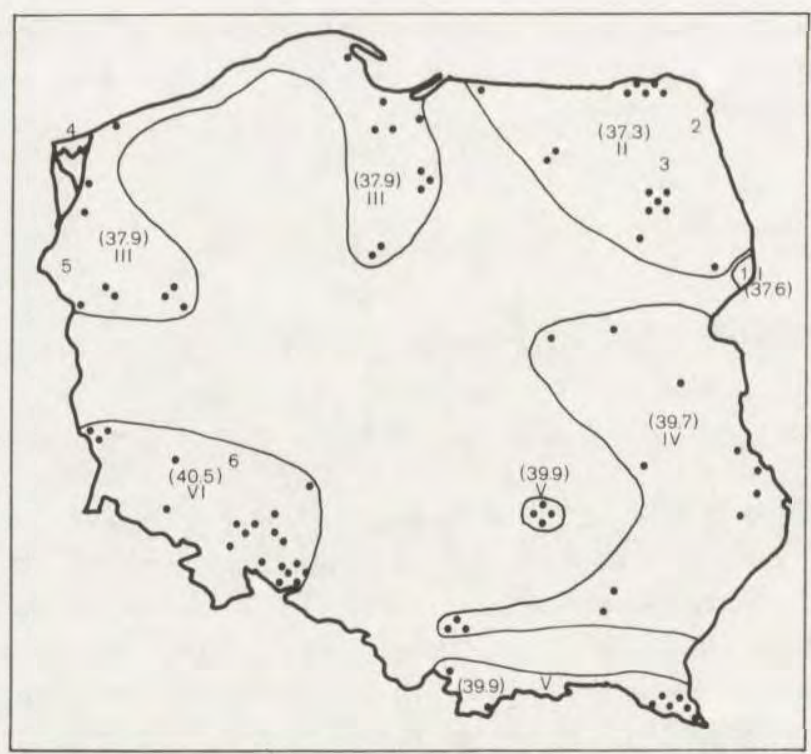

Fig. 1. Origin of material and distinguished regional groups (I - VI). Sites of captured single specimens are marked by points. Sites with more than 4 specimens are marked by Arabic numerals: $1=138,2=9,3=12,4=5,5=7,6=22$. 
Table 1. The numbers of examined Mustela nivalis skulls with respect to sex, age classes $(1-3)$, and geographical regions.

\begin{tabular}{lrrrrrrrrr}
\hline \multirow{2}{*}{ Region } & \multicolumn{3}{c}{ Males } & & \multicolumn{3}{c}{ Females } & Total \\
\cline { 2 - 4 } \cline { 7 - 8 } & 1 & 2 & 3 & & 1 & 2 & 3 & \\
\hline I. Białowieża Primeval Forest & 7 & 20 & 37 & & 5 & 19 & 50 & 138 \\
II. North-East Reg. & 11 & 5 & 3 & & 9 & 2 & 6 & 36 \\
III. North-West Reg. & 5 & 14 & 5 & & 2 & 2 & 3 & 31 \\
IV. South-East Reg. & - & 1 & 5 & & - & 5 & 2 & 13 \\
V. Mountainous Reg. & - & 1 & 6 & & - & 4 & 1 & 12 \\
VI. Lower Silesia & 3 & 8 & 23 & & 1 & 2 & 4 & 41 \\
\hline Total & 26 & 49 & 79 & & 17 & 34 & 66 & 271 \\
\hline
\end{tabular}
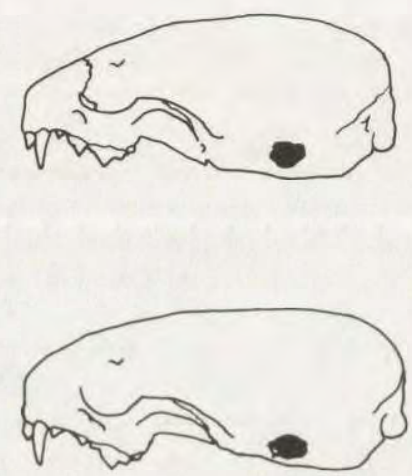

Fig. 2. Shape of the skull in different age classes: A - young specimen up to 3 (4) months "triangular", $\mathrm{B}$ - specimen between $5-6$ months "medial", C specimen above 6 months "rectangular".

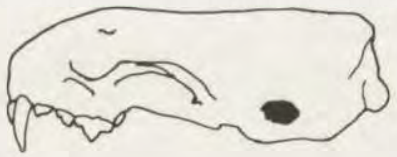

C

(2) General skull appearance. The surface structure of the frontal and parietal bones were described as either "smooth" or "rough" (spongiose). Development of occipital and saggital crests and mastoid processes (by Buchalczyk and Ruprecht 1977). The shape of the skull was differentiated as: "triangular", "rectangular" or "medial" (Fig. 2).

(3) Postorbital-interorbital ratio.

(4) Time of death.

On the basis of above criteria three age classes were distinguished:

Class 1 - age approximately $3-4$ months. The viscerocranial sutures are loose and well visible (possibly partly ossified). The surface structure of the frontal and parietal bones is spongiose and rough. No crests or mastoid processes are present. The shape of the skull is "triangular" (Fig. 2A). Postorbital breadth exceeds interorbital constriction. The brain-case is larger and more "puffed up" than in older specimens (Heptner et al. 1974). Pressuming the possibility of two litters in the weasel, 

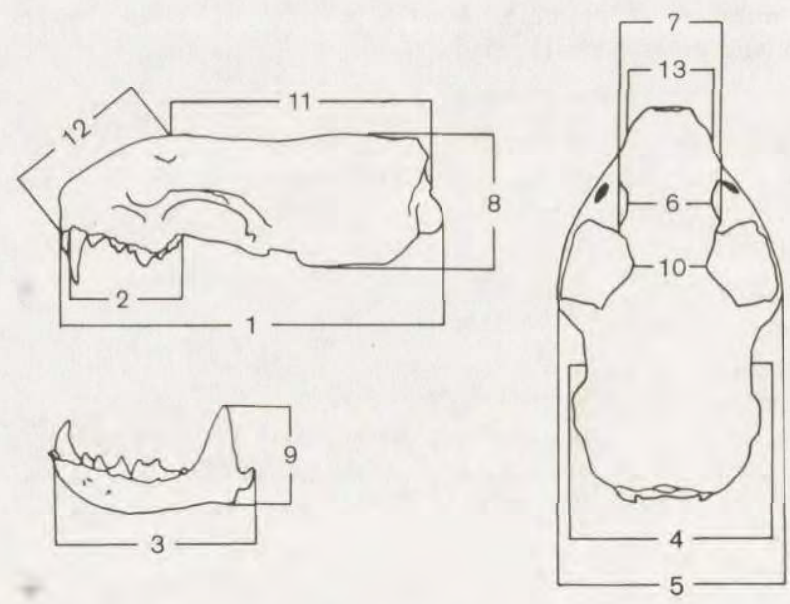

Fig. 3. Methods for making measurements in skulls of $M$. nivalis: $1-\mathrm{CbL}, 2-\mathrm{MxTRL}, 3-\mathrm{MdL}, 4-$ $\mathrm{BcB}, 5$ - ZyB, 6 - IC, 7 - EctB, 8 - BcH, 9 - HRM, 10 - PB, 11 - BcL, 12 - VcL, 13 - RB. Definitions of measurements are given in the text.

in May - June and in August (Deanesly 1944, Frank 1974, King 1980), then this class incorporates the specimens which died in the July - October period.

Class 2 - age about 5-6 months. The viscerocranial sutures are still visible, but already ossified. The surface structure of the skull bones is less rough. In some specimens the occipital crest and mastoid processes start to develop. The skull profile is medial between "triangular" and "rectangular" (Fig. 2B). The postorbital breadth equals, or slightly exceeds interorbital constriction. Specimens which died in November and December belong in this class.

Class 3 - age above 6 months. The viscerocranial sutures are completely ossified, and almost or totally unvisible. The bones' surface is smooth. The occipital crest and mastoid processes are always present but vary in size in particular specimens. In the oldest specimens the saggital crest is distinctly developed. The skull shape is "rectangular"(Fig. 2C). Postorbital breadth is less than interorbital constriction. This class incorporates specimens which died within one year.

\section{Geographical groups}

The material was divided into geographical groups according to the lowest annual temperature distribution in Poland. This criteria was accepted as one of the probable factors affecting the body size of mammals (Rosenzweig 1968). The possibility of a more precise division was limited by the amount of material. Six geographical groups were distinguished: I - Białowieża Primeval Forest, II - NorthEast region, III - North-West region, IV - South-East region, V - mountainous regions $(400 \mathrm{~m}$ above altitude: Bieszczady Mountains, Tatra Mountains, Beskid Zywiecki Mountains, Swiętokrzyskie Mountains), VI - Lower Silesia (Fig. 1, Table 1). Group 1 includes specimens exclusively from the Białowieża Primeval Forest area, while other groups include specimens from considerably larger areas.

\section{Measurements and quotient indices}

The following 13 linear measurements were made using a slide caliper with an accuracy to the nearest $0.1 \mathrm{~mm}$ (Fig. 3):

1. Condylobasal length $(\mathrm{CbL})$,

2. Maxillary tooth-row length (MxTRL), 
3. Mandible length (MdL) - measured from the anterior margin of alveolus $I_{1}$ to the end of the articular mandible process,

4. Braincase breadth $(\mathrm{BcB})$,

5. Zygomatic breadth (ZyB),

6. Interorbital constriction (IC),

7. Ectoorbital breadth (EctB),

8. Braincase height $(\mathrm{BcH})$ measured per tympanic bullae,

9. Height of ramus mandibulae (HRM),

10. Postorbital breadth (PB),

11. Braincase length (BcL): opisthion - sagektorbion (after Wyrost and Kucharczyk 1967),

12. Viscerocranium length (VcL): prosthion - sagektorbion,

13. Rostrum breadth (RB) measured on $\mathrm{C}^{1}-\mathrm{C}^{1}$.

In order to ascertain the differences in the proportion of skull measurements in particular groups (age, sexual and geographical) 11 indices were calculated:

1. BcL $\times 100: \mathrm{CbL}$ (after Buchalczyk and Ruprecht 1977), 2. PB $\times 100:$ IC, $3 . \mathrm{IC} \times 100: \mathrm{BcB}, 4$. $\mathrm{BcB} \times 100: \mathrm{ZyB}, 5 . \mathrm{BcB} \times 100: \mathrm{CbL}, 6 . \mathrm{ZyB} \times 100: \mathrm{CbL}$ (after Buchalczyk and Ruprecht 1977), 7. $\mathrm{BcH} \times 100: \mathrm{CbL}, 8 . \mathrm{RB} \times 100: \mathrm{VcL}, 9 . \mathrm{RB} \times 100: \mathrm{BcB}, 10 . \mathrm{M} \times \mathrm{TRL} \times 100: \mathrm{CbL}, 11 . \mathrm{RB} \times 100: \mathrm{CbL}$.

\section{Mathematical methods}

Calculations were made of average values $(\bar{x})$, standard deviations (S.D.) and coeficients of variation (C.V.) for all skull measurements and indices. These parameters were used to characterize the absolute skull dimensions and proportion of weasels in relation to age and sex.

ANCOVA and discriminant analysis were used to: 1 . calculate the differences between groups in particular aspects of variation, 2. estimate the importance of measurements and indices for distinguishing particular groups, 3. estimate if the presented classification was correct (STATGRAPHICS programm). The significance levels $0.05>p>0.001$ and $p<0.001$ were accepted. The following measurements and indices were not included into the statistical analysis because of the relatively low data: PB (skulls damaged by parasitic Nematode - Skrjabingylus nasicola) (K. Schmidt, in prep.) and $\mathrm{BcH}$ (tympanic bulla damaged), as well as $\mathrm{PB} / \mathrm{IC}$ and $\mathrm{BcH} / \mathrm{CbL}$.

To determine the changes in development processes and growth rate of particular skull dimensions in late weasel ontogeny, the Pearson correlation matrices were used. This was illustrated graphically using Terentjev's method (1960). These matrices were also used to illustrate sexual dimorphism in different age classes.

\section{Results}

In Tables 2 and 3 the basic morphological characteristics of all measurements and indices with regard to age and sex are shown. The growth tendency, sexual dimorphism and geographical variation of weasel skull are presented below.

\section{Age variation}

In the examined skull samples an increase in absolute values in skull dimensions was not clearly evident (Table 4). The most intense increase in skull dimension occured in age class 3 . These dimensions were particularly concerned with the viscerocranium, i.e.: RB, EctB, MxTRL, HRM (Table 4). The female skulls nearly did not show an size increase in relation to age, excluding rostrum breadth (RB) (Table 4). For both sexes the absolute braincase dimension decrease was characteristic $(\mathrm{BcB}, \mathrm{BcH}, \mathrm{PB})$. This process was most intensely marked in females. 


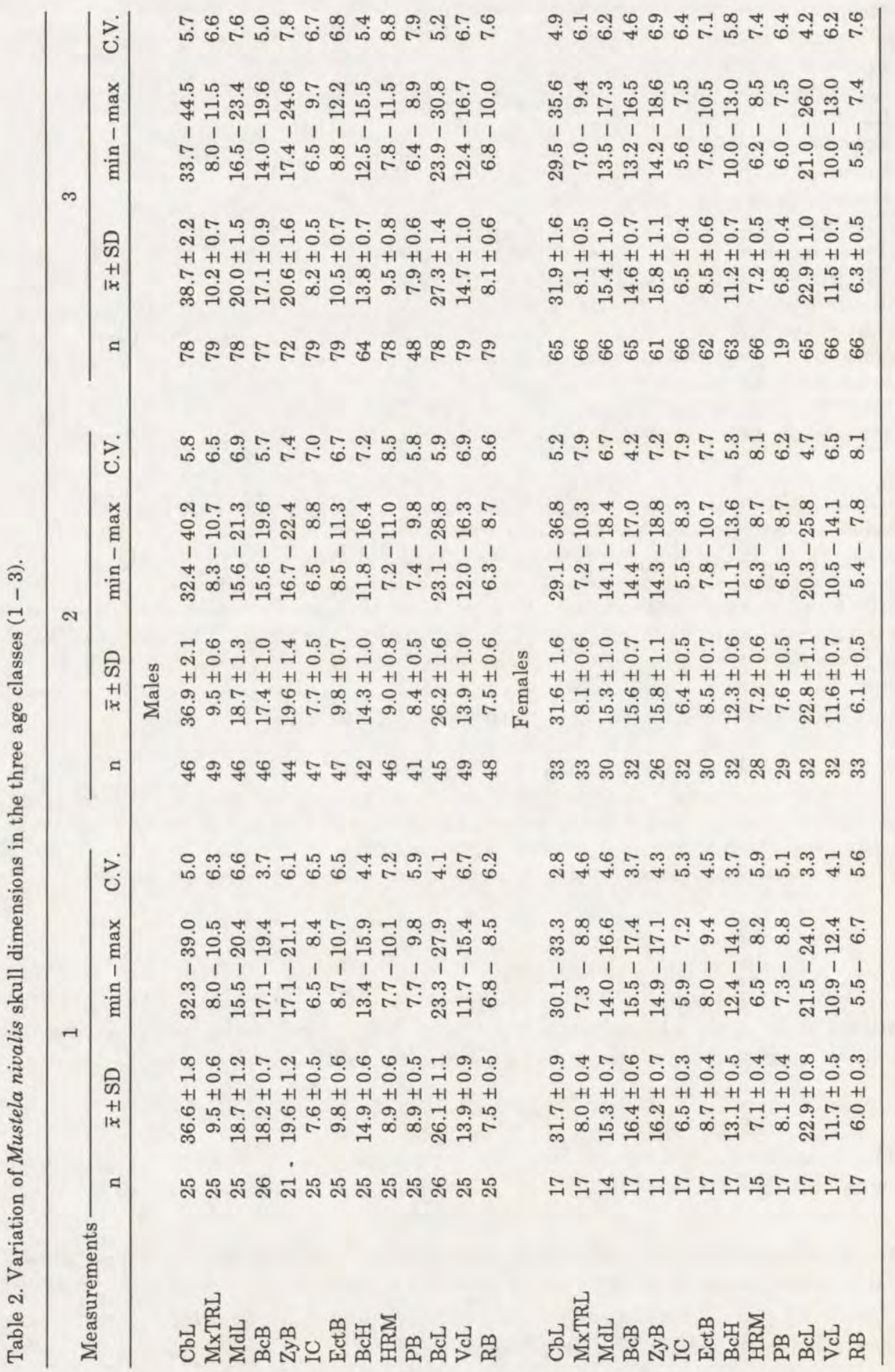


สำ

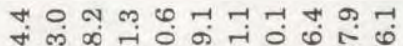
सำำ $\begin{array}{lllllllllll}1 & 1 & 1 & 1 & 1 & 1 & 1 & 1 & 1 & 1 & 1\end{array}$

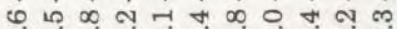

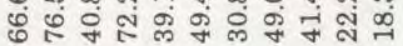

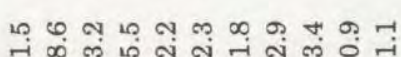
(1)

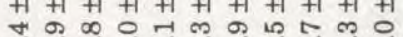

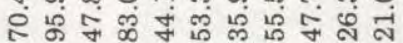

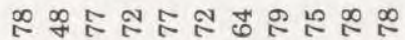

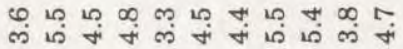
๓

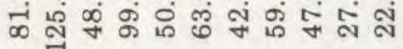
$\begin{array}{lllllllllll}1 & 1 & 1 & 1 & 1 & 1 & 1 & 1 & 1 & 1 & 1\end{array}$

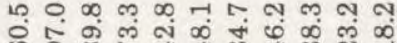

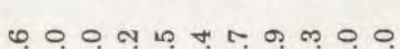

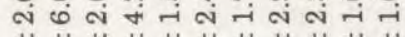
$+1+\mathrm{H}+\mathrm{H}+\mathrm{H}+\mathrm{H}+\mathrm{H}+\mathrm{H}+\mathrm{H}$ ๘ँ

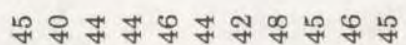

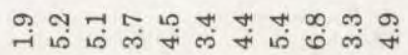
+

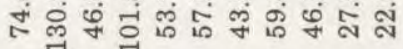

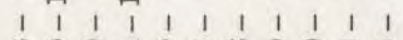

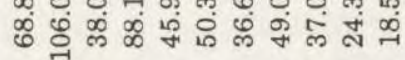

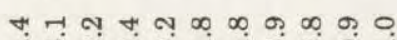

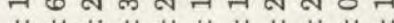
$+\mathrm{H}+\mathrm{H}+\mathrm{H}+\mathrm{H}+\mathrm{H}+\mathrm{H}+\mathrm{H}+\mathrm{H}+\mathrm{H}$

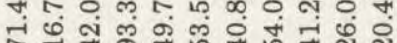

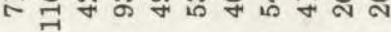

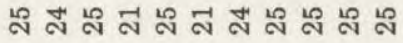

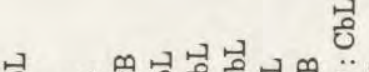

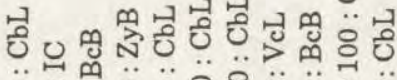
官 $\ddot{\circ} \ddot{\circ} \ddot{\circ} \circ \stackrel{\circ}{\circ} \ddot{\circ} \ddot{\circ} \ddot{\circ}$ $\times \vec{x} \times \vec{x} \times \vec{x} \vec{x} \times \vec{x}$

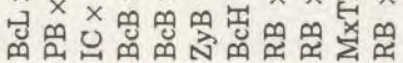

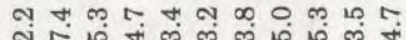

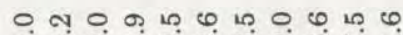

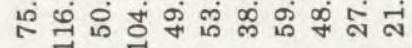
$\begin{array}{lllllllllll}1 & 1 & 1 & 1 & 1 & 1 & 1 & 1 & 1 & 1 & 1\end{array}$

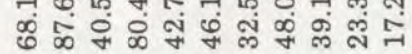

ம.

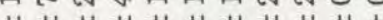
+1 $+11+11+110+10$

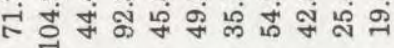

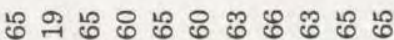

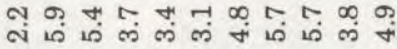
H

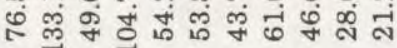
$\begin{array}{llllllllll}1 & 1 & 1 & 1 & 1 & 1 & 1 & 1 & 1 & 1\end{array}$ $\infty \infty$ m $\infty$ म

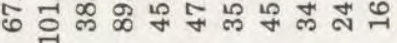

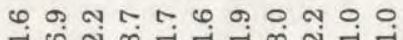
అ 0 क $+1+1+1+1+1$

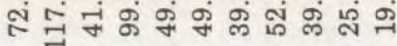

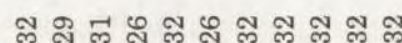

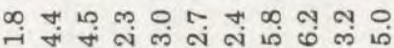

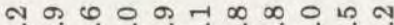
เ์ $\begin{array}{llllllllll}1 & 1 & 1 & 1 & 1 & 1 & 1 & 1 & 1 & 1\end{array}$

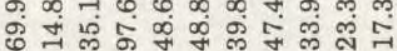
๓ H $+1+1+1+1+1+1+1+1+1+1$

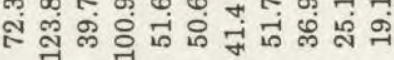
드드극도드드

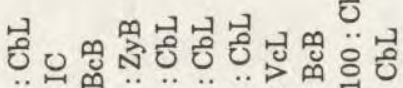

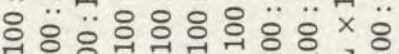

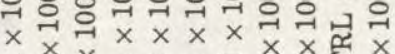

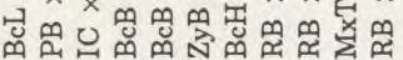


Table 4. Increase in percentages of Mustela nivalis skull dimensions and indices with regard to age (classes 2,3 ) and sex (average values for age class 1 were taken as $100 \%$ ).

\begin{tabular}{|c|c|c|c|c|}
\hline \multirow{2}{*}{ Measurements/Indices } & \multicolumn{2}{|c|}{ Males } & \multicolumn{2}{|c|}{ Females } \\
\hline & 2 & 3 & 2 & 3 \\
\hline $\mathrm{CbL}$ & 0.7 & 5.8 & -0.4 & 0.6 \\
\hline MxTRL & -0.6 & 7.1 & 1.4 & 1.8 \\
\hline $\mathrm{MdL}$ & -0.1 & 7.0 & 0.2 & 0.9 \\
\hline $\mathrm{BcB}$ & -4.2 & -6.0 & -4.8 & -10.9 \\
\hline $\mathrm{ZyB}$ & -0.1 & 5.1 & -2.2 & -2.4 \\
\hline IC & 0.5 & 7.1 & -1.0 & -0.4 \\
\hline EctB & -0.2 & 7.5 & -1.6 & -2.0 \\
\hline $\mathrm{BcH}$ & -3.8 & -6.9 & -6.4 & -14.7 \\
\hline HRM & 0.7 & 7.1 & 1.2 & 1.2 \\
\hline PB & -5.8 & -11.5 & -6.2 & -15.7 \\
\hline $\mathrm{BcL}$ & 0.4 & 4.4 & -0.5 & -0.3 \\
\hline $\mathrm{VcL}$ & 0.1 & 5.9 & -1.4 & -1.5 \\
\hline $\mathrm{RB}$ & 0.3 & 9.0 & 0.6 & 3.4 \\
\hline $\mathrm{BcL} \times 100: \mathrm{CbL}$ & -0.6 & -1.4 & 0.1 & -0.8 \\
\hline $\mathrm{PB} \times 100: \mathrm{IC}$ & -6.7 & -17.8 & -4.8 & -15.3 \\
\hline $\mathrm{IC} \times 100: \mathrm{BcB}$ & 5.1 & 14.0 & 3.7 & 11.8 \\
\hline $\mathrm{BcB} \times 100: \mathrm{ZyB}$ & -4.3 & -11.0 & -1.7 & -8.0 \\
\hline $\mathrm{BcB} \times 100: \mathrm{CbL}$ & -5.1 & -11.2 & -4.2 & -11.4 \\
\hline $\mathrm{ZyB} \times 100: \mathrm{CbL}$ & -1.2 & -0.5 & -1.8 & -2.2 \\
\hline $\mathrm{BcH} \times 100: \mathrm{CbL}$ & -4.7 & -12.1 & -5.8 & -15.1 \\
\hline $\mathrm{RB} \times 100: \mathrm{VcL}$ & 0.1 & 2.8 & 2.1 & 4.9 \\
\hline $\mathrm{RB} \times 100: \mathrm{BcB}$ & 4.5 & 15.8 & 5.7 & 16.0 \\
\hline MxTRL $\times 100: \mathrm{CbL}$ & -1.5 & 1.2 & 1.7 & 1.2 \\
\hline $\mathrm{RB} \times 100: \mathrm{CbL}$ & -0.7 & 2.9 & 1.2 & 2.8 \\
\hline
\end{tabular}

Table 5. The results of analysis of covariance and discriminant analysis (S.D.F.C. - Standarized Discriminant Function Coeficients) with respect to age.

\begin{tabular}{lrrlrr}
\hline Measurements & \multicolumn{1}{c}{$\mathrm{F}$} & S.D.F.C. & \multicolumn{1}{c}{ Indices } & \multicolumn{1}{c}{$\mathrm{F}$} & S.D.F.C. \\
\hline CbL & $14.9^{* *}$ & -1.29 & $\mathrm{BcL} \times 100: \mathrm{CbL}$ & $5.8^{*}$ & -0.10 \\
MxTRL & $15.9^{* *}$ & 0.10 & $\mathrm{IC} \times 100: \mathrm{BcB}$ & $93.2^{* *}$ & -0.35 \\
MdL & $16.1^{* *}$ & -0.84 & $\mathrm{BcB} \times 100: \mathrm{ZyB}$ & $86.4^{* *}$ & -3.25 \\
$\mathrm{BcB}$ & $45.0^{* *}$ & 2.37 & $\mathrm{BcB} \times 100: \mathrm{CbL}$ & $180.2^{* *}$ & 5.64 \\
$\mathrm{ZyB}$ & $6.8^{*}$ & -0.31 & $\mathrm{ZyB} \times 100: \mathrm{CbL}$ & 1.3 & -2.02 \\
$\mathrm{IC}$ & $14.0^{* *}$ & -0.16 & $\mathrm{RB} \times 100: \mathrm{VcL}$ & $8.2^{* *}$ & -0.61 \\
EctB & $15.0^{* *}$ & -0.03 & $\mathrm{RB} \times 100: \mathrm{BcB}$ & $103.5^{* *}$ & 5.24 \\
HRM & $9.1^{* *}$ & 0.21 & $\mathrm{MxTRL} \times 100: \mathrm{CbL}$ & 2.2 & 0.02 \\
BcL & $8.8^{* *}$ & -0.39 & $\mathrm{RB} \times 100: \mathrm{CbL}$ & $7.0^{*}$ & -3.30 \\
VcL & $9.1^{* *}$ & 1.06 & & & \\
RB & $20.6^{* *}$ & -0.59 & & & \\
\hline
\end{tabular}

${ }^{*}-0.05>p>0.001,{ }^{* *}-p<0.001$. Discriminant functions were significant at the level $p<0.001$. 

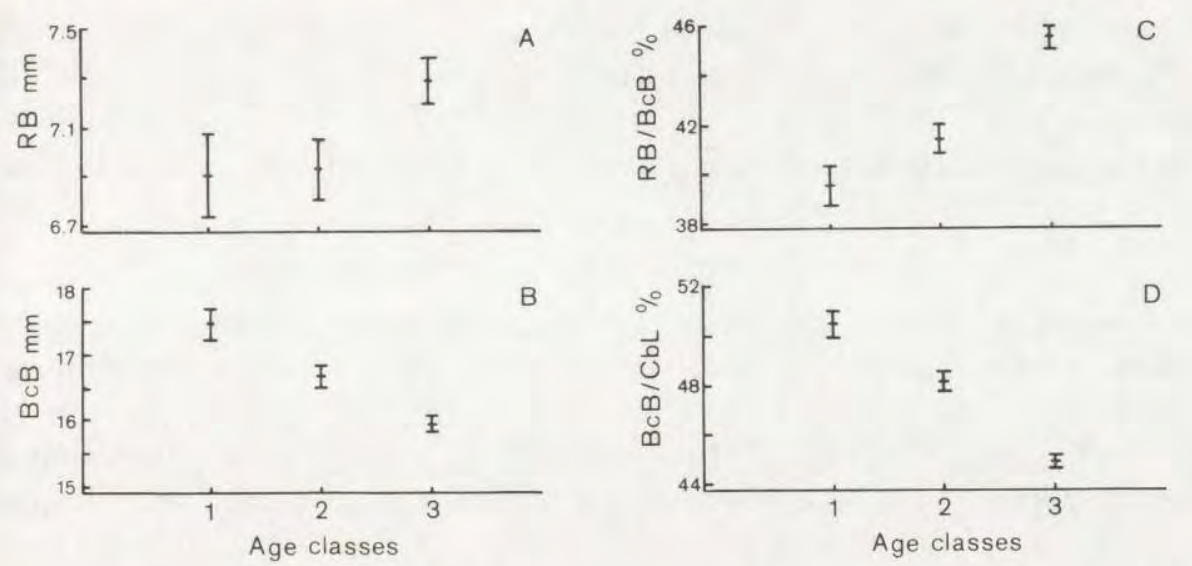

Fig. 4. Confidence intervals of two chosen measurements and two quotient indices according to the age aspect.

Table 6. Predicted classification of Mustela nivalis skulls with regard to the age classes according to the discriminant analysis.

\begin{tabular}{|c|c|c|c|c|c|c|c|}
\hline \multirow{3}{*}{ Age class } & \multicolumn{6}{|c|}{ Predicted classification in age classes: } & \multirow{3}{*}{$\begin{array}{c}\text { Total* } \\
\mathrm{n}\end{array}$} \\
\hline & \multicolumn{2}{|c|}{1} & \multicolumn{2}{|c|}{2} & \multicolumn{2}{|c|}{3} & \\
\hline & $\mathrm{n}$ & $\%$ & $\mathrm{n}$ & $\%$ & $\mathrm{n}$ & $\%$ & \\
\hline \multicolumn{8}{|c|}{ Measurements } \\
\hline 1 & 24 & 77.4 & 7 & 22.6 & 0 & 0.0 & 31 \\
\hline 2 & 10 & 15.9 & 46 & 73.0 & 7 & 11.1 & 63 \\
\hline 3 & 3 & 2.3 & 15 & 11.5 & 112 & 86.2 & 130 \\
\hline \multicolumn{8}{|c|}{ Indices } \\
\hline 1 & 22 & 68.8 & 10 & 31.3 & 0 & 0.0 & 32 \\
\hline 2 & 11 & 16.4 & 45 & 67.2 & 11 & 16.4 & 67 \\
\hline 3 & 0 & 0.0 & 14 & 10.9 & 114 & 89.1 & 128 \\
\hline
\end{tabular}

* - Fourty seven (measurements) and fourty four (indices) cases were excluded from analysis due to missing data.

The covariance analysis showed a significant difference between age classes, particularly in the cases of $\mathrm{BcB}$ and $\mathrm{RB}$ (Table 5, Fig. 4A, B). Age class 3 maintained a considerable dimensional separateness from class 1 and 2 (Fig. 4A). The predicted classification of skulls to this class amounted to $86 \%$ whereas in class $273 \%$ was determined and in class $1-77 \%$ (Table 6 ).

Contrary to absolute measurements, intensive changes in proportions took place. The braincase dimensions $(\mathrm{BcB} / \mathrm{CbL}, \mathrm{BcH} / \mathrm{CbL}$ and $\mathrm{PB} / \mathrm{IC})$ underwent a comparative diminution with age (Fig. 4D, Table 4). A strong, comparative growth was determined for viscerocranial indices: $\mathrm{IC} / \mathrm{BcB}$ (Table 4) and $\mathrm{RB} / \mathrm{BcB}$ (Fig. $4 \mathrm{C}$ ). 
Comparing the indices in the three age classes by means of covariance analysis and discriminant analysis, large significant differences were shown in: $\mathrm{BcB} / \mathrm{CbL}$, $\mathrm{RB} / \mathrm{BcB}$ (Fig. $4 \mathrm{C}, \mathrm{D}$ ), IC/BcB as well as in $\mathrm{RB} / \mathrm{BcB}$ (Table 5). Using all indices the specimens can be determined with an accuracy of $68 \%$ to class $1,67 \%$ to class 2 , and $89 \%$ to age class 3 (Table 6 ).

\section{Changes in correlation structures with age}

Correlation structures illustrated, by means of Terentjev's method (1960), the development processes taking place in the skull with respect to sex differences (Fig. 5).

Generally, the capacity of the pleiads which are highly interdependent characters (Terentjev's 1960 terminology) do not change during the lifespan in males $(r \geq 0.8)$. In females on the other hand the correlation structures demonstrated a dependence between the capacity of pleiads and age. The lowest capacity occured in class 1 , with a sudden increase in class 2 and a decrease again in class 3. In males and females of age class 1 the independent pleiads (on Fig. 5 these are the triangles not connected by secants) comprised of RB, HRM, and RB, MxTRL, PB respectively. Furthermore males were characterized by a large dependent pleiad including $\mathrm{CbL}, \mathrm{MxTRL}, \mathrm{MdL}, \mathrm{VcL}, \mathrm{BcL}$ and $\mathrm{ZyB}$, while for females the dependent pleiad consisted of 5 traits: $\mathrm{BcH}, \mathrm{HRM}, \mathrm{BcL}, \mathrm{CbL}$, and MdL.
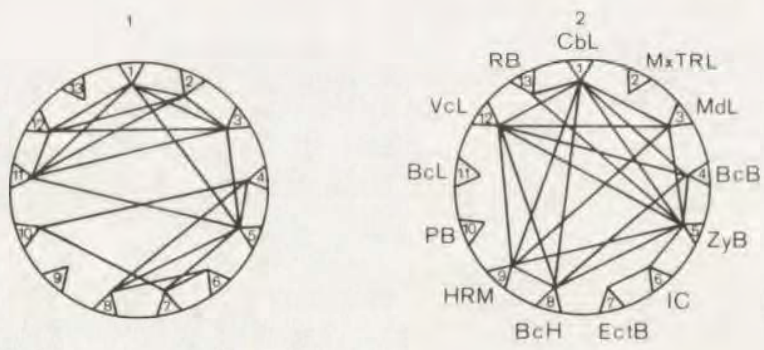

Males

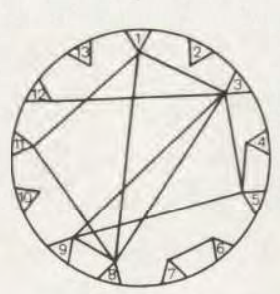

2

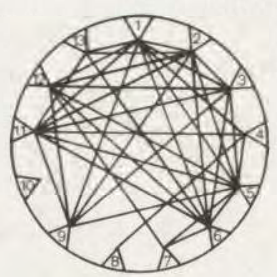

Females

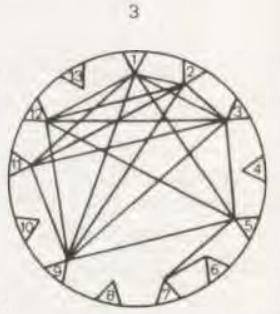

3

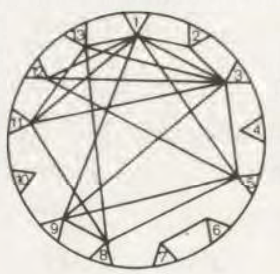

Fig. 5. Variation of correlation structures in $M$. nivalis according to age $(1-3)$ and sexual dimorphism. Only significant correlations where $r \geq 0.8$ were taken. 
In males of age class 2 three new independent pleiads appeared: MxTRL, PB and $\mathrm{BcL}$, whereas $\mathrm{RB}$ and HRM lost their independence. The connections of $\mathrm{BcH}$ and HRM with $\mathrm{CbL}, \mathrm{BcL}, \mathrm{VcL}$ and $\mathrm{MdL}$ also arose. In females the PB pleiad still remained independent and the connections between $\mathrm{BcH}, \mathrm{HRM}, \mathrm{BcL}, \mathrm{Cbl}$ and $\mathrm{MdL}$ disappeared. The degree of dependence among the remaining traits rapidly increased.

Independent pleiads in males of class 3 were represented by: $\mathrm{RB}, \mathrm{PB}, \mathrm{BcH}$ and $\mathrm{BcB}$, while in females only $\mathrm{PB}$ and the new independent pleiad - $\mathrm{BcB}$ became separated.

It is worth paying attention that independence is gained by those traits which illustrate reciprocal relations between the braincase and viscerocranium dimensions.

\section{Age differences in coefficients of variation}

Coefficients of variation (C.V.) in the absolute measurements and quotient indices of weasel skulls also varied with age. In the case of absolute measurements the lowest values were always in age class 1 (3.7 - 7.2 in males, $2.8-5.9$ in females), while the highest was in class 2 (5.7-8.6 in males, and $4.2-8.1$ in females) (Table 2). Although C.V. of indices were less dependent on age, some of them, particularly $\mathrm{PB} / \mathrm{IC}$ and $\mathrm{BcB} / \mathrm{ZyB}$ (in both sexes), distinctly increased with age. On the other hand $\mathrm{RB} / \mathrm{VcL}, \mathrm{RB} / \mathrm{BcB}$ and $\mathrm{RB} / \mathrm{Cbl}$ values in females decreased (Table 3). The largest variation was marked in the case of HRM in all age classes of both sexes, and RB (in class 2 of males as well as in classes 2 and 3 of females) and of indices - PB/IC (in classes 2 and 3 of both sexes) and $\mathrm{RB} / \mathrm{BcB}$ (in classes 1 and 3 of males and 1 and 2 of females). The lowest values of C.V. occured in the cases of $\mathrm{BcB}, \mathrm{BcL}, \mathrm{BcH}$, and $\mathrm{CbL}$ as well as $\mathrm{BcL} / \mathrm{CbL}, \mathrm{ZyB} / \mathrm{CbL}, \mathrm{BcB} / \mathrm{ZyB}$ and MxTRL/CbL.

\section{Sexual dimorphism}

Analysis of covariance of particular measurements (age and geographical variation was accepted as covariates) indicated that skulls of males were significantly larger than those of females $(p<0.001)$. This especially concerned such measurements as: MdL, $\mathrm{CbL}, \mathrm{VcL}, \mathrm{BcL}$ (Table 7, Fig. 6). The percentage classification of each sex on the basis of all the chosen measurements amounted to $92 \%$ for males and $99 \%$ for females (Table 8 ).

The skull proportions also varied according to the sex as resulted from a similar analysis based on indices. The largest differences occured in: $\mathrm{BcB} / \mathrm{ZyB}, \mathrm{RB} / \mathrm{BcB}$ and $\mathrm{ZyB} / \mathrm{CbL}$ (Table 7). The first index value was greater in females, whereas the other two had greater values in males (Table 3). On the basis of indices, the predicted sex classification was $92 \%$ for males and $82 \%$ for females (Table 8 ).

The sexual dimorphism of weasel skulls also became visible when the variation coefficients of absolute measurements and indices were compared. Generally, these were higher in males, especialy in age classes 1 and 3 (Table 2 and 3). MxTRL, 
Table 7. The results of analysis of covariance and discriminant analysis (S.D.F.C. - Standarized Discriminant Function Coeficients) with respect to sexual dimorphism.

\begin{tabular}{|c|c|c|}
\hline Measurements/Indices & $\mathrm{F}$ & S.D.F.C. \\
\hline $\mathrm{CbL}$ & 617.2 & -0.73 \\
\hline MxTRL & 525.3 & 0.06 \\
\hline MdL & 631.2 & 0.37 \\
\hline $\mathrm{BcB}$ & 447.6 & 0.30 \\
\hline $\mathrm{ZyB}$ & 548.3 & 0.31 \\
\hline IC & 518.9 & 0.32 \\
\hline EctB & 356.9 & -0.33 \\
\hline HRM & 548.8 & -0.01 \\
\hline $\mathrm{BcL}$ & 592.4 & 0.40 \\
\hline VcL & 606.8 & 0.38 \\
\hline $\mathrm{RB}$ & 565.9 & 0.13 \\
\hline $\mathrm{BcL} \times 100: \mathrm{CbL}$ & 28.9 & -0.09 \\
\hline $\mathrm{IC} \times 100: \mathrm{BcB}$ & 88.1 & 0.21 \\
\hline $\mathrm{BcB} \times 100: \mathrm{ZyB}$ & 231.4 & 5.45 \\
\hline $\mathrm{BcB} \times 100: \mathrm{CbL}$ & 63.3 & -3.77 \\
\hline $\mathrm{ZyB} \times 100: \mathrm{CbL}$ & 157.5 & 2.39 \\
\hline $\mathrm{RB} \times 100: \mathrm{VcL}$ & 19.1 & 0.66 \\
\hline $\mathrm{RB} \times 100: \mathrm{BcB}$ & 173.2 & 0.95 \\
\hline MxTRL $\times 100: \mathrm{CbL}$ & 31.7 & -0.10 \\
\hline $\mathrm{RB} \times 100: \mathrm{CbL}$ & 109.6 & -1.46 \\
\hline
\end{tabular}

All measurements and quotient indices are significant at the level $p<0.001$

Table 8. Predicted classification of Mustela nivalis skulls with regard to sex according to the discriminant analysis.

\begin{tabular}{|c|c|c|c|c|c|}
\hline \multirow{3}{*}{ Sex } & \multicolumn{5}{|c|}{ Predicted attachment to: } \\
\hline & \multicolumn{2}{|c|}{ Males } & \multicolumn{2}{|c|}{ Females } & \multirow{2}{*}{$\begin{array}{c}\text { Total } \\
\mathrm{n}\end{array}$} \\
\hline & $\mathrm{n}$ & $\%$ & $\mathrm{n}$ & $\%$ & \\
\hline & \multicolumn{5}{|c|}{ Measurements } \\
\hline Males & 121 & 92.4 & 10 & 7.6 & 131 \\
\hline Females & 1 & 1.1 & 92 & 98.9 & 93 \\
\hline & \multicolumn{5}{|c|}{ Indices } \\
\hline Males & 121 & 91.7 & 11 & 8.3 & 132 \\
\hline Females & 17 & 17.9 & 78 & 82.1 & 95 \\
\hline
\end{tabular}



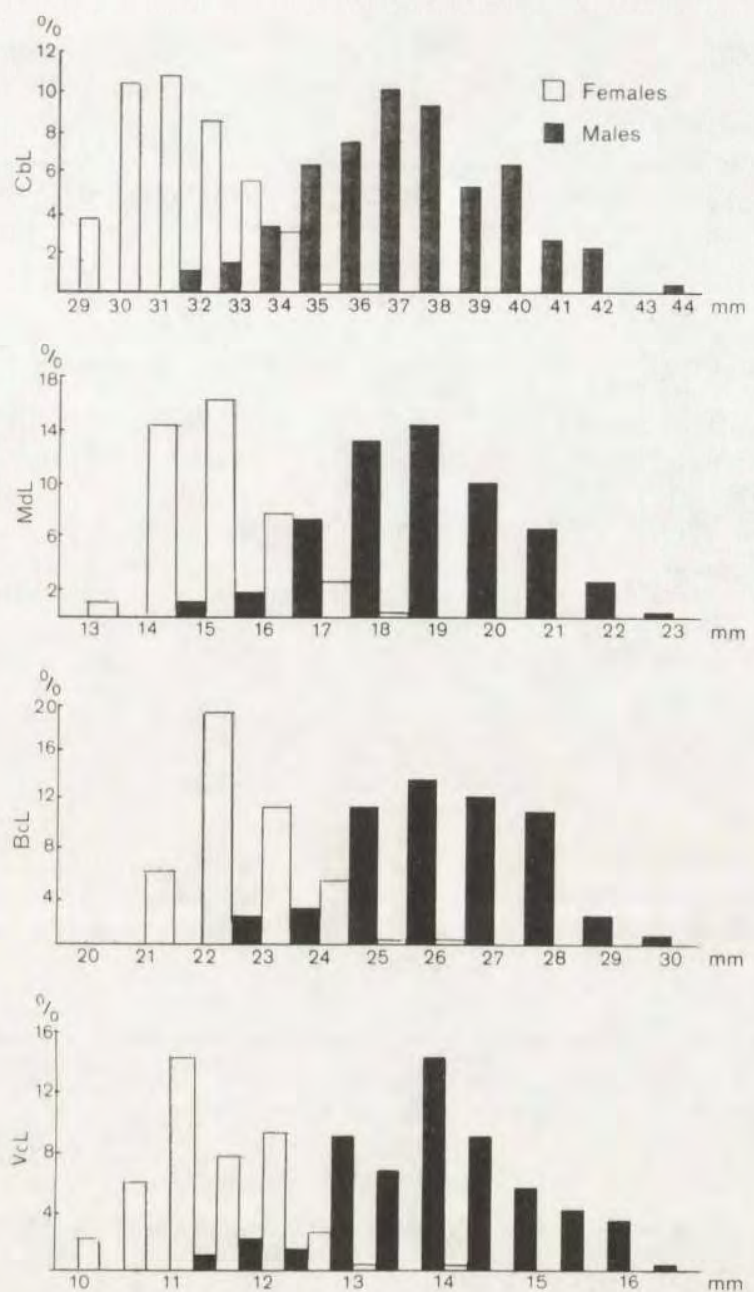

Fig. 6. Variation distributions of certain M. nivalis skull measurements from Poland.

IC, EctB and PB were an exception in age class 2, as these values were greater in females. In the case of C.V. of indices only three: $\mathrm{BcL} / \mathrm{CbL}, \mathrm{BcB} / \mathrm{ZyB}$ and $\mathrm{ZyB} / \mathrm{CbL}$ applied to this rule.

\section{Geographical differentiation}

All the features used in the covariance analysis in relation to the geographical aspect (sex and age variation was accepted as covariates) showed significant $(0.05$ $>p>0.001$ ) differences among geographical regions (Table 9). From confidence interval plots (Fig. 7), the differences between region I (Białowieża Primeval Forest) and region VI (Lower Silesia) were the most distinct. Primarily this 
Table 9. The results of analysis of covariance and discriminant analysis (S.D.F.C. - Standarized Discriminant Function Coeficients) with respect to the geographical aspect.

\begin{tabular}{lcrr}
\hline Measurements/Indices & F & S.D.F.C. I & S.D.F.C. II \\
\hline CbL & $7.9^{* *}$ & -1.05 & 1.99 \\
MxTRL & $7.0^{* *}$ & -0.80 & -0.46 \\
MdL & $11.0^{* *}$ & 1.17 & -1.42 \\
BcB & $2.9^{*}$ & 0.71 & 0.75 \\
ZyB & $12.8^{* *}$ & 2.25 & -0.05 \\
IC & $5.1^{* *}$ & 0.39 & 1.23 \\
EctB & $10.9^{* *}$ & 0.50 & -0.50 \\
HRM & $8.7^{* *}$ & -0.33 & -0.73 \\
BcL & $6.5^{* *}$ & -0.50 & -1.30 \\
VcL & $7.4^{* *}$ & -0.06 & 0.04 \\
RB & $4.0^{*}$ & -1.05 & -0.20 \\
BcL $\times 100: \mathrm{CbL}$ & 2.3 & -0.23 & -0.35 \\
IC $\times 100: \mathrm{BcB}$ & $2.8^{*}$ & -0.04 & 0.86 \\
$\mathrm{BcB} \times 100: \mathrm{ZyB}$ & $9.4^{* *}$ & -2.13 & -7.31 \\
$\mathrm{BcB} \times 100: \mathrm{CbL}$ & $2.7^{*}$ & 4.55 & 3.52 \\
$\mathrm{ZyB} \times 100: \mathrm{CbL}$ & $9.5^{* *}$ & -0.39 & -4.75 \\
$\mathrm{RB} \times 100: \mathrm{VcL}$ & $2.6^{*}$ & -0.13 & 0.50 \\
$\mathrm{RB} \times 100: \mathrm{BcB}$ & 1.5 & 4.08 & -4.93 \\
$\mathrm{M} \times \mathrm{TRL} \times 100: \mathrm{CbL}$ & $4.2^{*}$ & -0.32 & -0.18 \\
$\mathrm{RB} \times 100: \mathrm{CbL}$ & 1.4 & -2.91 & 2.60 \\
\hline
\end{tabular}

$*-0.05>p>0.001,{ }^{* *}-p<0.001$

Discriminant functions were significant at the level $p<0.001$.

concerned the following features: $\mathrm{ZyB}(\mathrm{F}=12.8), \mathrm{MdL}(\mathrm{F}=11.0), \mathrm{EctB}(\mathrm{F}=10.9)$, as well as HRM ( $\mathrm{F}=8.7$ ) (Table 9).

Region I measurements were always the lowest. The skull samples examined in relation to $\mathrm{ZyB}, \mathrm{HRM}, \mathrm{MdL}$, and $\mathrm{CbL}$ were divided into two basic parts (Fig. 7). The first consisted of the Lower Silesia region (VI) (characterised by the highest values), this way it's exceptionally distinct character could be shown. The second part consisted of all the other groups. Three size classes were distinguished by means of the EctB measurement. The lowest class was the Białowieża Primeval Forest (I), while the highest ones were regions VI, IV and V (Fig. 7).

From discriminant analysis, $\mathrm{ZyB}$ and $\mathrm{MdL}$ (and to a lesser extend $\mathrm{CbL}$ and $\mathrm{RB}$ ) were discovered to be the most important for differentiating regions I, VI and II (Fig. 8, Table 9). CbL, MdL, IC and $\mathrm{BcB}$ showed special morphological distinctness in region VI and to a lesser degree in region II (Fig. 8, Table 9). With all measurements taken into account, the percentage classification of these specimens amounted $61 \%$ in region I, $65 \%$ in region VI and $73 \%$ in region II (Table 10). 

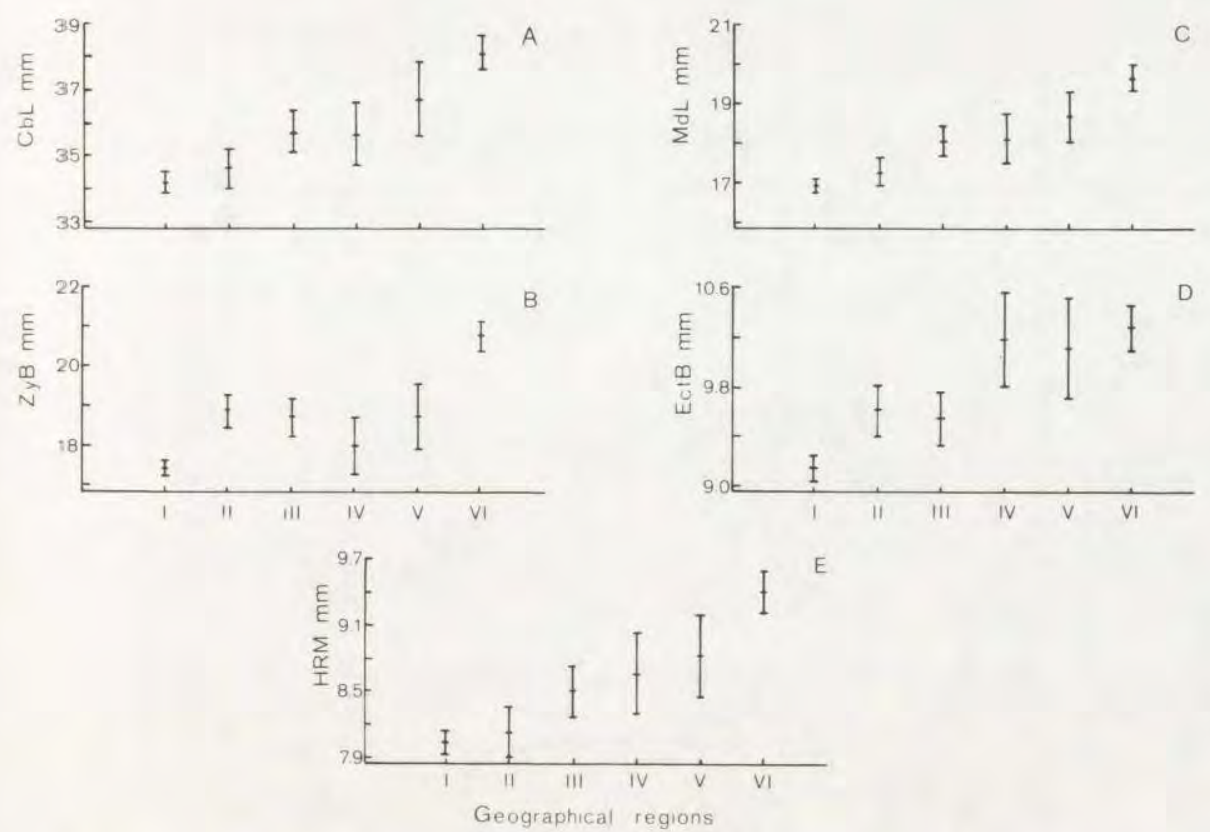

Fig. 7. Confidence intervals of chosen measurements according to the geographical aspect. See text for an explanation of the region numbers.

The most significant differences among the regional groups in relation to analysis of covariance of indices were in the cases of $\mathrm{BcB} / \mathrm{ZyB}$ and $\mathrm{ZyB} / \mathrm{CbL}$ (Table 9). The first index indicated that skulls from region VI were wider at the zygomatical arches and narrower within the braincase than the skulls from other regions. The second index, on the other hand, divided the examined material into three size classes. The first, characterized by the lowest ratio $\mathrm{ZyB}: \mathrm{CbL}$ incorporated regions I and IV, while the third class which had the widest zygomatical arches, comprised of regions VI and II (Fig. 9).

In the discriminant analysis the following indices: $\mathrm{BcB} / \mathrm{CbL}, \mathrm{RB} / \mathrm{BcB}$ and $\mathrm{BcB} / \mathrm{ZyB}$ were most significant (Table 9). First of all these indices separated regions I and II. Additionally, $\mathrm{ZyB} / \mathrm{CbL}$ is the index by which one can distinguish region VI (Fig. 8, Table 9). Classification of specimens in region I amounted to $48 \%$ in region VI $-50 \%$ and in region II $-67 \%$ (Table 10 ).

It can be appreciated that $\mathrm{CbL}$ is one of the features most dependent on the geographical region where the weasels were catched. Fig. 1 presents the distribution of these average values in adult males, according to regions distinguished. One can notice the distinct tendency towards the enlargement of this dimension in a north-east to south-west direction. 


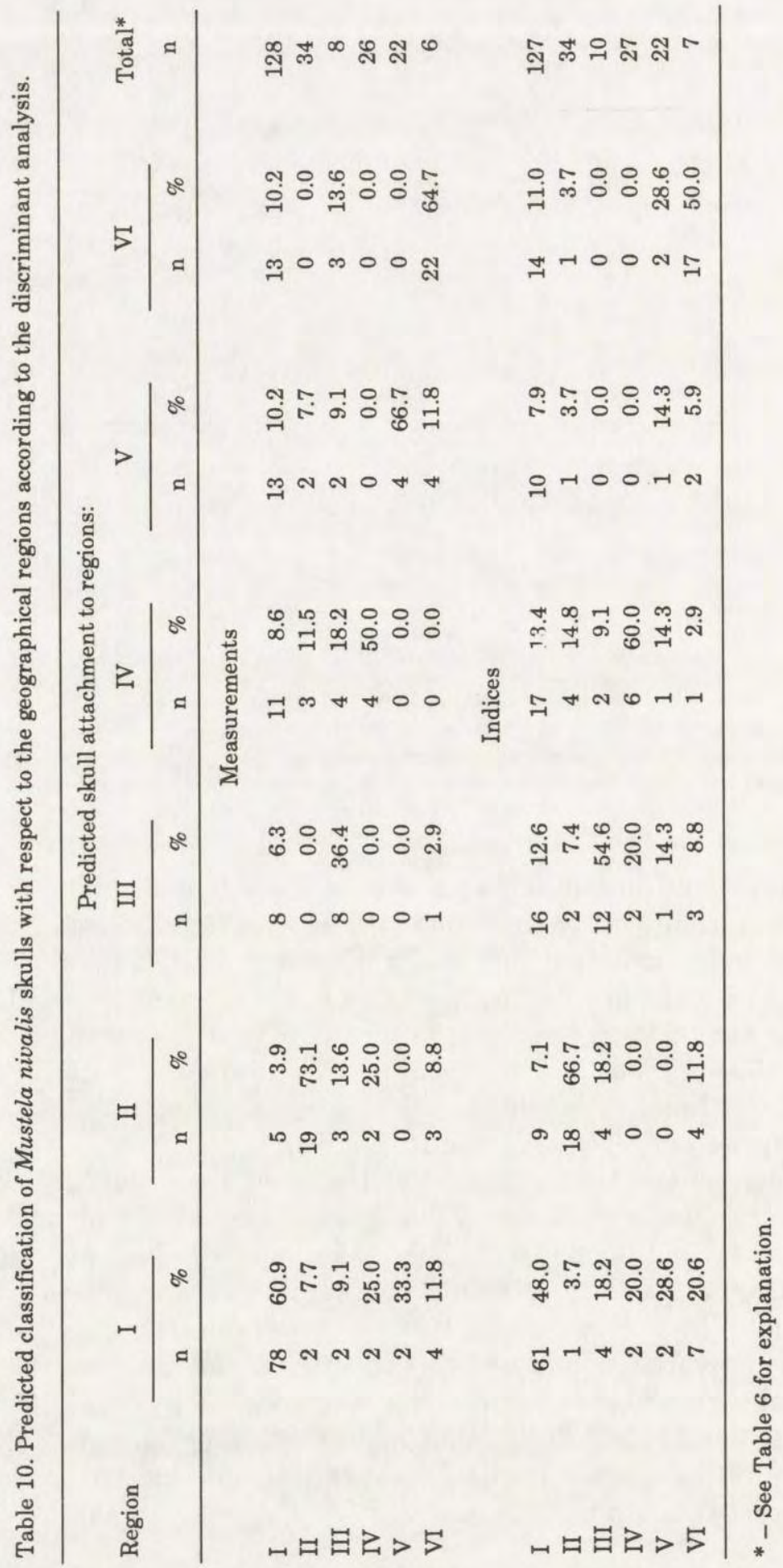


Fig. 8. Geographical group centroids (I - IV) from the discriminant analysis of measurements (A) and quotient indices (B).
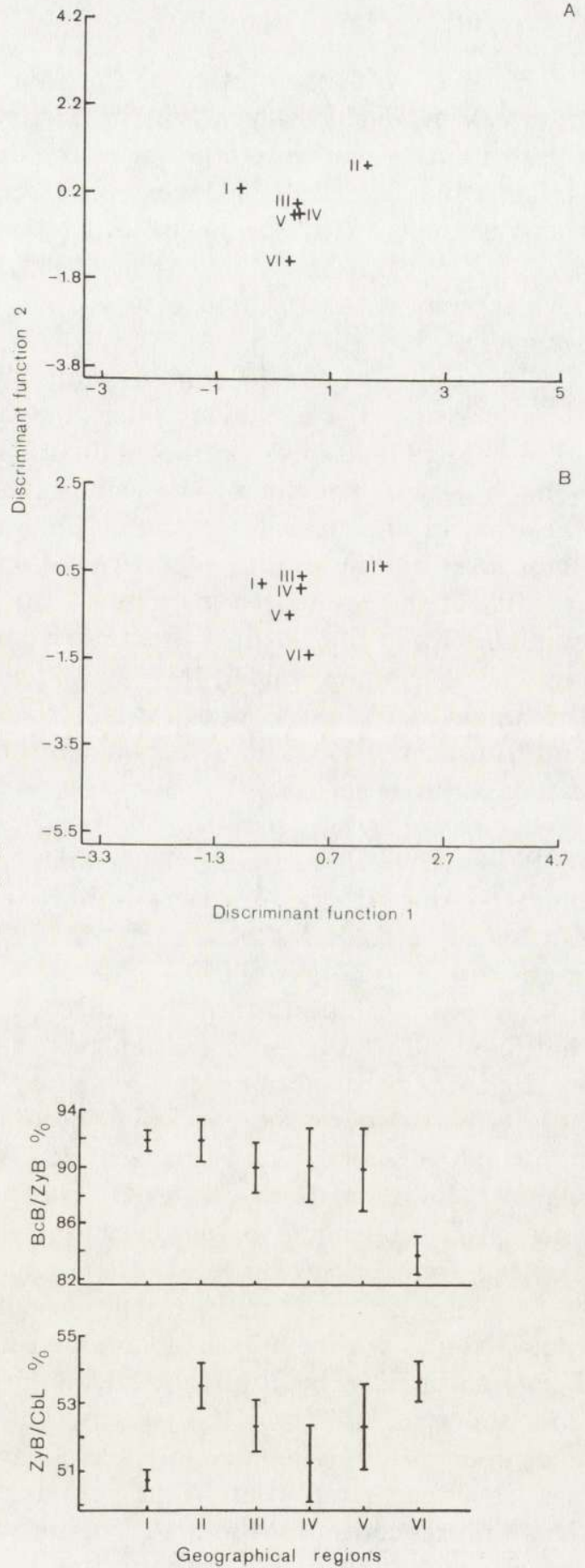

Fig. 9. Confidence intervals of certain quotient indices with respect to the geographical aspect. 


\section{Discussion}

Up till now, age variation of the weasel skull has not been analysed to any great extent. Besides several methodical papers (e.g. Grue and Jensen 1979, King 1980), a superficial characteristic in the development of the weasel skull can only be found in a few studies. Ognev (1962) and Heptner et al. (1974) only generalised about changes in the braincase and viscerocranium dimensions and postorbital breadth in relation to age. Fog (1969) commented about the saggital crest development with age, and also growth of the skull length in early postnatal ontogeny.

The results of the presented study show that the weasel skull reaches it's definitive size at the moment when the young are able to leave the nest (in June - July). Fog (1969) also expressed a similar opinion. Such a state can cause great homogeneity in size among the youngest animals (low values in the coeficients of variation in age class 1 ). In the oldest weasels the most evident changes taking place were in the skull proportions. Consequently, individual variation in the rapidity of this processes increases - the greatest value of C.V. in age classes 2 and 3 occurs in the features characterizing those parts of the skull which undergo significant changes during the weasel's life. In allied species - Mustela putorius the highest values of C.V. are in age class 1, and decrease with age (Buchalczyk and Ruprecht 1977). This phenomenon the Authors explained by the considerably extended birth period.

The tendency of decreasing braincase measurements corresponding with age, in $\mathrm{BcB}$ and $\mathrm{BcH}$, found in the examined material have been noticed in other mustelids i.e. diminishment in braincase capacity with age (in Enhydra lutris, Martes martes, Meles meles: Herán̆ 1973; Mustela putorius: Buchalczyk and Ruprecht 1977; Mustela vison: Kruska 1979). This phenomenon is also manifested by narrowing of postorbital breadth which is connected with temporal muscle development, and bone resorption occuring in the postorbital area (Wiig 1982).

Contrary to the braincase area, the viscerocranial dimension increases with age. Greater increases can be noticed in male weasels, similarly in Mustela putorius (Buchalczyk and Ruprecht 1977) as well as in the pine marten (Martes martes) (Reig and Ruprecht 1989). As Erlinge (1975) showed, significant differences exist in feeding habits between male and female weasels. Thus, one can expect a connection between these phenomena to exist.

The correlation structure variation during the life of the weasel, as stated, is inconsistent with the results obtained hitherto by Cabon-Raczyńska (1964) for Lepus europaeus, by Ruprecht (1974) for Ondatra zibethica and by Buchalczyk and Ruprecht (1977) for the polecat. The common feature in these three species is a decrease in dimensional interdependence with age, and, in the last two mentioned, an alternation in the periods of synchronous growth and stabilization. This difference can be the result of omitting the most intensive growth stage in the weasel ontogeny, when the young are unable to leave the nest. 
The correlation structures in both sexes also illustrate sexual dimorphism in particular age classes. The male skull was characterized by a stable, relatively low number of dependent pleiads during the whole male life, while in the females of class 2 the number of reciprocal connections intensively increases. This may indicate a set-back in the differentiating process in skull proportions in females of this period. The retention of young weasel skull features in adult females is a final effect of this phenomenon (King 1980) - a relatively large braincase as well as a narrow and short rostrum.

The sexual dimorphism in the weasel from Poland was definite by larger absolute measurements in the male skull than in the female. This is also well known from earlier descriptions concerned with the weasel, as well as with other species of the Mustela genus (Reichstein 1957, 1986; Pohle 1970, Ralls and Harvey 1985). Greater increases in the dimensions as well as generally greater values of C.V. found in male skulls may suggest, that the developing processes last longer in males than in females. This remains in accordance with King's (1991) data, by which female weasels reach adult size earlier than males.

The skull size of the weasel from Poland was increased from the north-east to the south-west (Fig. 1). In comparison, Bergmann's rule is reversed for different species of Carnivora, and described many times (e.g. in the weasel and the stoat: Reichstein 1957, Ralls and Harvey 1985, Erlinge 1987 and other species: Rosenzweig 1968). It is explained by such factors as: the effect of prey size, total primary productivity at given areas or latitude. However, no factors explain this problem sufficiently.

The morphological separateness in skulls from Lower Silesia is especialy distinct. This principaly lies in the proportional increase in zygomatic breadth towards braincase breadth (Fig. 9), as well as the retention of the exceptionally large size when compared with the skulls from other regions. In Silesia, Kleinschmidt (1937) described and Zimmermann (1940) confirmed the occurence of a new subspecies of weasel - Mustela nivalis trettaui. However, many authors vary in their opinion of the systematic status of this taxon. Heptner et al. (1974) considers this subspecies as the synonym of Mustela nivalis vulgaris. Kratochví (1977), on the other hand upholds the taxonomical separateness of the trettaui form, but as natio of $M$. nivalis boccamela. If condylobasal length can be the main criterion to distinguish among $M$. nivalis subspecies in Europe (Kratochvíl 1977), then dimensions similarity of males from Lower Silesia region and males of trettaui form given by Zimmermann (1940) seem to be surprisingly high (Table 11). Therefore the possibility of Mustela nivalis trettaui occurence on Lower Silesia cannot be definitively excluded.

Besides the trettaui subspecies, Reichstein (1957) suggests, for Poland the existence of nivalis as well as vulgaris, but he doesn't adduce any records in support of this assumption. The nearest area to Poland with respect to Reichstein's (1957) data is derived from the north German lowlands. Comparing CbL averages of males from this area and from northern Poland (Table 12) one can conclude, 
Table 11. A comparison of the CbL frequency distributions, variation ranges and average values of $M$. nivalis trettaui (by Zimmermann, 1940) with $M$. nivalis from Lower Silesia.

\begin{tabular}{|c|c|c|c|c|c|c|c|c|c|c|c|c|}
\hline & \multicolumn{10}{|c|}{$\mathrm{CbL}(\mathrm{mm})$} & \multirow[b]{2}{*}{$\bar{x}$} & \multirow[b]{2}{*}{$\mathrm{n}$} \\
\hline & 35 & 36 & 37 & 38 & 39 & 40 & 41 & 42 & 43 & 44 & & \\
\hline M. n. trettaui & 1 & 1 & 3 & 3 & 8 & 22 & 13 & 13 & 7 & & 40.5 & 71 \\
\hline $\begin{array}{l}\text { M. nivalis from } \\
\text { Lower Silesia }\end{array}$ & & & 1 & 1 & 2 & 7 & 5 & 4 & & 1 & 40.7 & 21 \\
\hline
\end{tabular}

Table 12. A comparison of the CbL variation ranges and average values among adult males of $M$. nivalis vulgaris, $M$. nivalis nivalis and $M$. nivalis from Poland (Lower Silesia excluded).

\begin{tabular}{|c|c|c|c|c|}
\hline Subspecies & $\min -\max$ & $\bar{x}$ & $\mathbf{n}$ & Author \\
\hline \multirow[t]{3}{*}{ M. nivalis vulgaris } & $36.3-43.9$ & 39.7 & 10 & Ognev (1962) \\
\hline & $31.5-43.0$ & 38.8 & $?$ & Heptner et al. (1974) \\
\hline & $30.1-42.4$ & 36.1 & 144 & Reichstein (1957) \\
\hline \multirow[t]{2}{*}{ M. nivalis nivalis } & $31.7-37.1$ & 34.7 & 14 & Ognev (1962) \\
\hline & $30.5-40.2$ & 35.3 & 13 & Heptner et al. (1974) \\
\hline M. nivalis from north Germany & $34.4-42.8$ & 37.1 & 53 & Reichstein (1957) \\
\hline \multicolumn{5}{|l|}{ M. nivalis from Poland: } \\
\hline I. Białowieża Primeval Forest & $33.7-41.0$ & 37.6 & 37 & This paper \\
\hline II. North-East Region & $35.4-38.7$ & 37.3 & 3 & $4 \quad$ \\
\hline III. North-West Region & $36.3-39.5$ & 37.9 & 5 & “ \\
\hline IV. South-East Region & $37.8-42.3$ & 39.7 & 5 & “ \\
\hline V. Mountainous Regions & $38.3-41.6$ & 39.9 & 6 & “ \\
\hline
\end{tabular}

that both samples belong to the same subspecies. The subspecies vulgaris inhabits the area behind the east border of Poland with great probability (Ognev 1962, Heptner et al. 1974), whereas, there is no agreement concerning the range of nivalis. Ognev (1962) considered this subspecies is characteristic for northern Sweden, Norway and common in Poland. Heptner et al. (1974) determined this taxon for the northern part of Europe except Finland and the northern part of the Scandinavian Peninsula. Observing the variation ranges and average values of $\mathrm{CbL}$ in both subspecies, after different authors (Table 12), one can see great variation in this dimension yet no apparent differences between subspecies. Additionally it seems, that the values deduced for the weasel from Poland (Lower Silesia region excluded) combine both subspecies' characters to some extent. Thus, to recapitulate, that at least in Poland both subspecies should not be distinguished as separate. As matters stand, the comparatively low average value of $\mathrm{CbL}$ is accepted as characteristic for Mustela nivalis nivalis (34.7 - 35.3) along with the 
comparatively high values of this dimension for the skulls from northern and southeastern Poland (37.3 - 39.9). One can then say that the weasels from Poland (except the Lower Silesia region), may rather belong to the subspecies Mustela nivalis vulgaris Erxleben, 1777.

In the light of these deductions, the statement that weasels in Poland belong to subspecies Mustela nivalis nivalis as accepted by Buchalczyk (1984), seem to be sceptical.

Acknowledgements: I wish to thank Professor Z. Pucek for examining the manuscript and his numerous valuable comments. Special thanks are also due to my wife Hanna for her help in taking skull measurements. I am grateful to Dr. W. Jędrzejewski and Dr. W. Bogdanowicz for their help in the statistical analysis and to Mr Ewen McNeish for his correction of the English.

\section{References}

Barbu P. 1968. Systematique et écologie de la belette (Mustela nivalis) provenant de quelques forts des district d'Ilfov et de Prahova - Roumanie. Trav. Mus. Hist. Natur. "G.Antipa” 8: 991-1002.

Buchalczyk T. 1984. Drapieżne - Carnivora. [In: Klucz do oznaczania ssaḱ6w. Z. Pucek, ed.]. PWN Polish Sci. Publ., Warszawa: $256-310$.

Buchalczyk T. and Ruprecht A. L. 1977. Skull variability of Mustela putorius Linnaeus, 1758. Acta theriol. 22: $87-120$.

Caboń-Raczyńska K. 1964. Correlations of skull measurements of Lepus europaeus Pallas, 1778. Acta theriol. 8: 207 - 216 .

Deanesly R. 1944. The reproductive cycle of the female weasel (Mustela nivalis). Proc. Zool. Soc. Lond. 114: $339-349$

Douma-Petridou E. and Ondrias J. C. 1987. Contribution to the taxonomy and geographical distribution of the weasel (Mustela nivalis) on the southern Balkan Peninsula. Säugetierkundl. Mitt. 33: $235-243$.

Erlinge S. 1975. Feeding habits of the weasel (Mustela nivalis) in relation to prey abundance. Oikos 26: $378-384$.

Erlinge S. 1979. Adaptive significance of sexual dimorphism in weasels. Oikos 33: $233-245$.

Erlinge S. 1987. Why do European stoats (Mustela erminea) not follow Bergmann's rule? Holarctic Ecol. 10: $33-39$.

Fog M. 1969. Studies on the weasel (Mustela nivalis) and the stoat (Mustela erminea) in Denmark. Danish Rev. Game Biol. 6: 1 - 14.

Frank F. 1985. Zur evolution und systematik der kleinen Wiesel (Mustela nivalis Linnaeus,1766). Z. Säugetierk. 50: $208-225$,

Grue H. and Jensen B. 1979. Review of the formation of incremental lines in tooth cementum of terrestrial mammals. Dan. Rev. Game Biol. 11, 3: 1- 48.

Heptner V. G., Naumov N. P., Jurgenson P. B., Sludskij A. A., Cirikova A. F. and Bannikov A. G. 1974. Die Säugetiere der Sovjetunion. Sekühe und Raubtiere. VEB Gustav Fischer Verlag Jena: 1 1004.

Herán I. 1973. Some results of investigations in braincase capacity of Mustelidae. Vest. cs. spol. zool. 37: $161-172$.

King C. M. 1975. The home range of the weasel (Mustela nivalis) in an English woodland. J. Anim. Ecol. 44: 639-668.

King C. M. 1980. Age determination in teh weasel (Mustela nivalis) in relation to the development of the skull. Z. Säugetierk. 45: $153-173$.

King C. M. 1991. Weasel Mustela nivalis. [In: The handbook of British mammals, G. B. Corbet and S. Harris, eds]. Blackwell Scientific Publications, Oxford: 387 - 396. 
Kleinschmidt O. 1937. Das Mauswiesel Schlesiens. Falco 33: 10 - 12.

Kratochvíl J. 1951. Koľavy a koľ̌avky v Ceskoslovensku. Sbor. VSZ, Brno 1: 61 - 148.

Kratochvil J. 1977. Sexual dimorphism and status of Mustela nivalis in Central Europe (Mamm., Mustelidae). Acta Sc. Nat. Brno 1: 61 - 148.

Kruska D. 1979. Vergleichende Untersuchungen an den Schädeln von subadulten und adulten Farmnerzen (Mustela vison f. dom.: Mustelidae; Carnivora). Z. Säugetierk. 44: $360-375$.

Lever C. 1985. Naturalized mammals of the world. Longman, New York: 1 - 487.

Mazák V. 1970. Poznamky k problému formy Mustela minuta (Pomel, 1853). Lynx, n.s. 11: 40 - 44.

Ognev S. J. 1962. Mammals of Eastern Europe and Northern Asia. Israel Program for Scientific Translations, Jerusalem: $1-590$.

Pohle C. 1970. Biometrishe Untersuchungen am Schädel des Farmnerzes (Mustela vison). Z. wiss. Zool. 181: $179-218$.

Ralls K. and Harvey P. H. 1985. Geographic variation in size and sexual dimorphism of North American weasels. Biol. J. Linn. Soc. 25: 119 - 167.

Reichstein H. 1957. Schädelvariabilität europäischer Mauswiesel (Mustela nivalis L.) und Hermeline (Mustela erminea L.) in Beziehung zu Verbreitung und Geschlecht. Z. Säugetierk. 22: 151 - 182.

Reichstein H. 1986. Beitrag zur Kenntnis des Sexualdimorphismus von Mustela nivalis Linné, 1766 und $M$. erminea Linné, 1758 nach Untersuchungen an postcranialen Skeletten aus SchleswigHolstein. Ann. Naturhist. Mus. Wien 88/89, B: $293-304$.

Reig S. and Ruprecht A. L. 1989. Skull variability of M. martes and M. foina from Poland. Acta theriol. 34: $595-624$.

Rosenzweig M. L. 1968. The strategy of body size in Mammalian Carnivores. Am. Midl. Nat. 80: $299-315$.

Ruprecht A.L. 1974. Craniometric variations in Central European populations of Ondatra zibethica (Linnaeus, 1766). Acta theriol. 19: 463 - 507.

Terentjev P. V. 1960. Dalniejsije razvitie metoda korrelacionnyh plejad. [In: Primenenije Matematǐeskich Metodov v Biologii. P. V. Terentjev, ed.]. Izd. Leningr. Univ. Leningrad: $27-36$.

Wiig O. 1982. Bone resorption in the skull of Mustela vison. Acta theriol. 27: 358 - 360 .

Wyrost P. and Kucharczyk J. 1967. Analysis einiger Parameter des ich ihres morphologischen Wertes. Acta theriol. 12: $293-322$.

Zimmermann K. 1940. Zur Kenntnis deutscher Maus- und Zwerg-wiesel. Z. Säugetierk. 15: 289 - 297.

Received 15 April 1992, accepted 15 May 1992. 